\title{
Evaluation of Candidate Teacher Training Process from the Viewpoint of Mentor Teachers
}

\author{
Ramazan Alabaş ${ }^{1}$, İhsan Yılmaz ${ }^{1}$ \\ ${ }^{1}$ Department of Educational Sciences, Kastamonu University, Kastamonu, Turkey \\ Correspondence: Ramazan Alabaş, Faculty of Education, Department of Educational Sciences, Kastamonu University, \\ Kastamonu, Turkey.
}

Received: July 22, 2018

Accepted: August 22, 2018

Online Published: August 29, 2018

doi:10.11114/jets.v6i11.3462

URL: https://doi.org/10.11114/jets.v6i11.3462

\begin{abstract}
Teacher education has been one of the most debated topics in history of Turkish education. At the beginning of the teacher's career, the Turkish Ministry of National Education (MONE) implemented the Candidate Teacher Training Program in 2016, so the teachers accepted to the profession were qualified as "candidate teachers" and they were subjected to the training process. The aim of this research is to examine the opinions of the mentor teachers regarding the Candidate Teacher Training Program implemented by the Turkish MONE for the training of candidate teachers. This research, which is a qualitative case study, was conducted with the participation of 36 teachers who are mentors to candidate teachers within the Candidate Teacher Training Program in the schools, which were affiliated to MONE in Kastamonu province center and its districts. The data of the study were collected by means of a semi-structured interview form. The data obtained in the research were analyzed with descriptive analysis and content analysis approaches. Mentor teachers thought that the Candidate Teacher Training Program is beneficial because the program provided the candidate teachers with the opportunities to identify students, acquire educational-instructional competence, acquire managerial knowledge, and identify the school and the social environment. However mentor teachers stated that they have experienced some problems related to the process such as filling in forms, some problems resulting from the candidate teacher, and time inadequacy.
\end{abstract}

Keywords: candidate teacher, teacher training system, mentor teacher, teacher qualifications

\section{Introduction}

Education, teaching and teaching profession, one of the factors of social change, constitutes the social aspect of education (Akyüz, 2012). The formal aspect of education takes place in schools with their own specific tasks, interaction processes, patterns, values and norms, and a hierarchical system (Celkan, 2014). Teachers have great duties in fulfilling the social and educational duties of schools as well. The most important factor directly affecting the quality of education systems is the teachers who are practitioners of the system. No matter how well-founded the education systems are and how well the programs are prepared, the success of the system depends on the teachers who will operate it and implement the programs (Duman, 2014). Teacher is an indispensable element of human development system in every society (Genç, 2005). Teachers play important roles and have duties in determining the quality of the human power and the nature of education institutions as they are both preparing and applying all the elements of the education system. Therefore, teacher education and the qualities of the teacher's profession have been one of the most important topics discussed in the history of Turkish education.

In Turkey, in order to acquire vocational formation besides vocational recognition, it is accepted as a basis for the teacher training system to make "practice studies" for the candidate teachers in terms of offering the opportunity of teaching on-the-job. In Turkish teacher training system the School Experience course and Teaching Practice course, which aim to establish a bridge between theory and practice in education for the application of these theoretical knowledge learned in schools and real classrooms, are implemented as well as general cultural knowledge and professional branch knowledge (branch didactics) (Yılmaz \& Kab, 2013). The Council of Higher Education (COHE, Yüksek Öğretim Kurulu-YÖK) expressed that the programs being implemented in the education faculties are largely compatible with the various dimensions of the teacher education programs used in teacher education in the EU countries. The programs applied in this context are generally designed as 50\% field knowledge and skills, 30\% teaching 
occupation knowledge and skills, 20\% general knowledge courses (COHE, 2006). During the School Experience and Teaching Practice classes in the program, the opportunity to practice was also given to the candidates not only in city centers but also in united classes at village and at regional boarding secondary schools.

Experiences of teacher candidates, gained in Teaching Practice course, can help them overcome the problems that may be experienced during both the candidacy and teaching process (Ulubey, 2018). In this context, no matter how well they are trained, the candidates who are graduated from the institutions educating the teachers may encounter some difficulties in the first years of the profession as a result of the inadequacy of professional experience. Some of the needs of novice teachers are classroom management, information about the school system, planning, organizing and managing instruction, motivating students, evaluating student progress and emotional support (Gordon \& Maxey, 2000). Eight problems of beginning teachers in their first years of teaching are classroom discipline, motivating students, dealing with individual differences, assessing students' work, relationships with parents, planning and organizing class work, insufficient teaching materials, and dealing with problems of individual students (Veenman, 1984). In the research conducted by Başar and Doğan (2015) at the beginning of the profession, it was stated that the teachers do not get the necessary guidance from managers and mentor teachers. They are inadequate in terms of classroom management and education process. In addition to this, they can't cope with unwanted behavior and had problems about social and cultural harmony with the environment. Toker and Gökçe (2013) implied that in the first years of working as a teacher, they are having difficulties in some areas such as teaching crowded classes, having education materials, keeping records about the students, establishing good relations with the inspectors and receiving professional guidance and support from the managers.

The problems faced by teachers in their early years can be seen on a wide range of topics ranging from professional issues to communicating with colleagues and defining the school system. In general, while performing a teaching profession, a teacher faces with its own rules of school culture, such as effective communication of education and teaching activities, as well as communication with students, school management, parents, and official correspondence with the environment and colleagues. Gaining competence in these matters is not only an experience but also a subject which requires time to overcome some of the challenges. In order to remove these difficulties or reduce, it is important for the teachers to prepare for the profession by giving them some trainings to the teachers in the first years of their profession. In each country, there are different implementations in the way of teacher training systems and the way to train the teachers at profession. In teacher education literature, support for teachers, who are entering the teaching profession, several terms have been used, such as "beginning teacher assistance programs", "clinical support programs", "teacher induction programs", and "mentor teacher programs" (Odell \& Ferraro, 1992, p.51). In Turkey, candidate teacher education program between 1995 and 2015 was carried out in accordance with the Regulation of Candidate Officers' Training published by the Ministry of National Education in 1995 (Yılmaz, 2017). In these applications, teachers were given training in basic education, preparatory education and practical education at the beginning of the profession. In this process, a mentor teacher was assigned to them. On April 17, 2015, the Ministry of National Education's Regulation on Appointment and Relocation of Teachers came into force, and it was required for the candidate teachers to participate in the written and oral exams provided that they were successful according to the actual study for at least one year and performance evaluation. The mentor teacher was also influential in this process of performance evaluation.

In 2016, the teachers who were admitted to the teaching profession by the Ministry of National Education (MONE) were defined as "candidate teachers" and assigned to a training institution, and an in-service program was started for the candidate teachers to be subjected to a training process called "Candidate Teacher Training Program". The first part of this program is planned as a six month training process. In this process, under the responsibility of the administrator of the educational institution and in the consultancy of the senior teachers who have certain qualifications and are assigned to them, the candidate teachers take training in different areas such as preparation, course planning and evaluation, classroom instruction, classroom practice and monitoring administrative, financial, social and cultural activities and taking part in them. These trainings are also evaluated separately by the administrator of the training institution that the candidate teacher has worked for and by the mentor teacher under the name of "Performance Evaluation". Therefore, in this application for the training of teachers, besides the trainings that they received before the service, there is a great duty of the administrator and the mentor as a colleague who is assigned to him during the process of starting the profession.

In MONE Regulation on Appointment and Relocation of Teachers, mentor teacher is defined as a teacher who will be mentor during the candidate training process (MONE, 2016). The mentor concept is expressed in the Turkish Dictionary as "the person who is consulted to get information and thought, the consultant, the person who has knowledge and expertise in a certain subject and who is assigned to use his knowledge and opinions" (TDK, 2017). A mentor is a senior teacher who works with a novice teacher during the beginning of novice's ealy practices in the classroom (Boreen, 
Johnson, Niday \& Potts, 2009). Kwan \& Lopez-Real (2005, p.276) defines mentor as "normally an experienced teacher who takes up the responsibility of 'looking after' a mentee when he/she does the practicum (or internship) in a school". The mentor teachers are the novice teachers' basic instructors, and mentors serve as role models (Klieger \& Oster-Levinz, 2015). Moreover, the mentor may offer the mentee recommendation, protection and support (Ambrosetti \& Dekkers, 2010). Similarly, Smith (2007, p.277) describes mentoring as "a particular mode of learning wherein the mentor not only supports the mentee, but also challenges them productively so that progress is made".

In Turkey, the obligations of the mentor teachers have been determined according to the Regulation of Candidate Teacher Training Process, which was enacted with the Authority No 2456947 and dated 02.03.2016. According to this, the mentor teachers were held responsible for the training of the candidate teachers in the process of applying the training program determined by the MONE to the first six months of their candidacy. Mentor teachers should have at least ten years of professional experience in addition to teaching the same field as the candidate teacher, and they are required to participate in national or international projects and social and cultural activities as well as to have the powerful communication skills and competence in representation and profession.

For the evaluation of the candidate teachers' performance in the candidate teacher education institution, the mentor teachers are required to observe the candidate in the context of the professional criteria and to guide him in the whole performance evaluation process in this direction (Resmi Gazete [Official Gazette], 2015). During the Candidate Teacher Training Program, it has been accepted as a basis that mentor teachers supervise the classes that the candidate teachers will teach (MONE, 2016). The other duties of the mentor teachers are to prepare the work program of the candidate teachers together with the administrator of the training institution, to assist the candidate teacher in taking the activities in the prepared work program, to take the necessary precautions, to monitor, to evaluate and to guide in order to train the candidate teachers in accordance with the work programs as well as educational guidance in the implementation of this program. In addition to these educational guidance, mentor teachers are models of their professional knowledge, skills, attitudes and behaviors, and the task of transferring their experiences is also among the duties given to the mentors (MONE, 2016). Mentor teachers were held responsible to the educational institution staff for carrying out all these tasks (MONE, 2016).

Training programs were organized by MONE under the name of "Candidate Teacher Training Process Mentor Teacher Training Seminars" in order to inform and train the mentor teachers at the beginning of the process. After these trainings were completed between 22-29 February 2016, the mentor teachers who will take part in the Candidate Teacher Training Program were informed about the program, the roles and expectations in this program. Thus, senior teachers who will become mentors in terms of exchanging the experiences have been prepared for the Candidate Teacher Training Program. Such programs, which can also be defined as training courses for candidate teachers, are an important opportunity for the novice teachers to get to know the various aspects of their profession, especially in the first years of their profession. In this context, different aspects of the teacher training program that is being implemented for teachers who are already in the profession can give more detailed information about the program. It is necessary to evaluate the Candidate Teacher Training Program from the point of view of practitioners. In terms of effectiveness of the program, it is important to determine the opinions of the mentor teachers who are given the duty to train candidate teachers in the Candidate Teacher Training Program. Considering the studies made on this subject in Turkey. 20 mentor teachers' ideas working in Tokat city center and Zile district of Tokat province were determined about the Candidate Teacher Training Program to evaluate it from the point of mentor teacher by Şayir and Yardibi (2017). According to this, the mentor teachers stated that the Candidate Teacher Training Program contributes positively to the professional development of the candidate teachers. Apart from this research, besides the candidate teachers, there are studies in which the opinions of the mentor teachers are evaluated (Topsakal \& Duysak, 2017, Tunçbilek \& Tünay, 2017, Tünay, 2017, Pala, 2017, Apaydın, Çelik Şahin \& Karasu, 2017, Dursun, Bulut \& Yenen, 2016, Toprakçı \& Ölmez Ceylan, 2017).

\subsection{Purpose of the Study}

It is thought that this study is important in terms of applying the program efficiently and giving some advices about it as there are not so many studies analyzing the Candidate Teacher Training Program in the literature in the aspect of mentor teacher at different perspectives. In this context, the purpose of the research is to evaluate the Candidate Teacher Training Program in various aspects according to the opinions of the mentor teachers. For this purpose, answers to the following questions were searched according to the opinion of the mentor teachers: (1) What is the effectiveness of the Candidate Teacher Training Program?, (2) What are the contributions of the Candidate Teacher Training Program to the candidate teachers?, (3) What are the considerations about the difficulties encountered in the Candidate Teacher Training Program?, (4) What is the recommendation for planning the Candidate Teacher Training Program more effectively? 


\section{Method}

In this research, we used case study, a qualitative research method. A case study involves developing an in-depth description and analysis of a case, providing an in-depth understanding of case (Creswell, 2007). The most basic feature of case study is the depth evaluation of one or several situations. In other words, the factors related to a situation (environment, individual, events, processes, etc.) are investigated with a holistic approach and they are focused on how they affect the situation and how they are affected by the situation (Yıldırım and Şimşek, 2013). The case study provides an opportunity for the researcher to investigate in depth, intervene, and find inferences about the influence, or relationship on the individual, the participant, or society without interfering with one another (Akar, 2016).

\subsection{Participants}

The study group of the research is 36 teachers who are assigned as mentor teachers to the candidate teachers in the schools where the Candidate Teacher Training Program is applied in Kastamonu province center and in the provinces of Araç, Küre, Pınarbaşı, Taşköprü and Tosya. Among the purposive sampling methods, maximum variation sampling which is frequently used in qualitative researches was used for determining the study group. In variation sampling, the results of the research are not intended to be generalized directly to the general, but rather the aim is to describe and understand in depth the person or situation studied (Ekiz, 2009). The purpose of creating a sample based on the maximum variation is to create a small sample and to reflect the diversity of the individuals that can be the subject of the problem in this sample to the maximum extent (Yıldırım and Şimşek, 2013). In this kind of sampling, the aim is not to provide this diversity, but rather to try to find out whether there are any common or shared phenomena among the diversity of the cases and to show the different dimensions of the problem according to this diversity (Yıldırım and Şimşek, 2013). In this study, in order to provide diversity, the participants were determined according to the age, vocational seniority and branch type. 10 mentor teachers participating in the research work in primary school, 12 in secondary school and 14 in high school (Anatolian high school, vocational high school, religious vocational high school). 20 of the mentors participating in the research are in Kastamonu city center and 16 of them are in the districts (Araç, Taşköprü, Tosya, Küre and Pınarbaş1). In the study group, 2 of the mentor teachers are between the ages of 28-29 years, 9 of them are between 30-38, 11 of them are between 36-40, 6 of them are between 40-44 and 6 of them are between 44-48, 2 of them are 48 years old and over. 3 of the mentor teachers in the study have 10-12 years working experience, 9 of them have 12-15 years' experience, 10 of them have 15-18 years, 7 of them have 18-21 years, 5 of them have 21-24 years, 2 of them have 24 years. The participants are teachers of pre-school, primary school, social studies, science and technology, guidance, English, electricity, visual arts, physics, crafts, furniture, Turkish, physical education, Turkish language and literature, chemistry and history branch.

\subsection{Data Collection and Analysis}

In this research, semi-structured interview form prepared by researchers were used as data collection method. For the semi-structured interview questions prepared for mentor teachers, opinions of three experts were taken, pilot interviews were made with 5 mentor teachers and the clarity of questions was tested. The final form of the interview form consists of two parts, personal information in the first part; and a) effectiveness of the candidate teacher training program, b) contributions to the candidate teachers, c) considerations about the applied activities, d) questions about what the proposals are for planning the program more effectively in the second part.

Validity and reliability in the qualitative research is different from the quantitave research (Creswell, 2007, p.18). According to Lincoln \& Guba (cited in Creswell, 2007, p.18) instead of using quantitative terms such as internal and external validity, and generalizability, the qualitative researcher writing a case study may employ terms such as credibility, and transferability. According to Lincoln \& Guba; Erlandson, Harris, Skipper \& Allen (cited in Yıldırım and Şimşek, 2013, p.305) in qualitative research, it is preferred to use the concept of credibility in place of internal validity, transferability in place of external validity. For this reason, in the study diversity approach was used for credibility, and participants with different characteristics were included in the study. A detailed description for transferability and an objective sampling approach that allows for additional sampling in the process was preferred. Lincoln \& Guba; Erlandson, Harris, Skipper \& Allen (cited in Yıldırım and Şimşek, 2013, p.305) argue that for credibility, long-term interaction, depth-oriented data collection, diversification, expert review and participant confirmation methods and for transferability the detailed description and purposive sampling methods are used. The participants volunteered for the interviews, and the answers were analyzed by descriptive analysis and content analysis techniques. In descriptive analysis, a set of data is first described systematically and explicitly, then these descriptions are explained and interpreted, and direct citations are frequently given to reflect the views of individuals in a striking way (Yıldırım and Şimşek, 2013). In content analysis, categorization is done to measure the concepts and to make a certain meaning (Tavşanc1 \& Aslan, 2001). For this purpose, the collected data were coded by "thematic coding" method and the data were described using direct citations from the mentor teachers' views. In using the opinions of the mentor teachers with 
direct citation, the code numbers T1, T2, T3 were used, giving the teacher code number from 1 to 36 , without using the participant names.

As a result of the content analysis, tables were created for the categories obtained. In order to ensure the reliability researchers coded the collected data separately. Apart from the researchers, in the creation of the codes and categories, the opinions of two experts in the field of qualitative research were taken into consideration and the categories were finalized. Moreover, in order to ensure the reliability Miles \& Huberman's (1994, p.64) "[Reliability=Agreement/(Agreement+Divergence)]" formula was used. The reliability ratio between the researchers was $87 \%$.

\section{Results}

The research findings have been analyzed under four titles: "mentor teachers' opinions about the effectiveness of the Candidate Teacher Training Program, the contribution of the program to the candidate teachers according to the mentor teachers, the difficulties encountered in the program and the recommendations of the mentor teachers about the program."

\subsection{Opinions of Mentor Teachers on the Effectiveness of the Candidate Teacher Training Program}

"What is your opinion about the effectiveness of the Candidate Teacher Training Program" was asked to the mentor teachers to determine the effectiveness of "The Candidate Teacher Training Program". The answers were as follows:

Table 1. Opinions regarding the effectiveness of the training program

\begin{tabular}{lll}
\hline \multicolumn{1}{c}{ Opinions } & f & \% \\
\hline It was an effective program & 26 & 72,22 \\
It was not an effective program & 5 & 13,88 \\
It was partially an effective program & 5 & 13,88 \\
\hline
\end{tabular}

As seen in the table above, 26 (72.2\%) of the mentor teachers indicated that the Candidate Teacher Training Program applied for the training of candidate teachers was an effective process, $5(13.8 \%)$ stated that the program was not effective and $5(13.8 \%)$ stated that it was partially effective. The views of the participants who expressed that the candidate education process is effective are shown in the following table:

Table 2. Distribution of the mentor teachers' opinions who found the program effectively

\begin{tabular}{ll}
\hline Expressions & Frequency \\
\hline Transfer of experience & 3 \\
Transfer of information & 1 \\
Seeing what to do and how to do it & 2 \\
Creating a positive perception change & 5 \\
Teacher ownership & 1 \\
Professional recognition & 6 \\
Adopting a profession & 2 \\
Overcome the excitement & 3 \\
Seeing and recognizing the functioning of the school & 2 \\
Integration with students & 1 \\
Self-improvement & 3 \\
Experience the beauty of the profession & 1 \\
Applying the knowledge gained in the faculty & 3 \\
Gaining confidence & 2 \\
Providing adaptation & 1 \\
\hline Total & 36 \\
\hline
\end{tabular}

As seen in the table 2, mentor teachers' evaluations on the Candidate Teacher Training Program as an effective training process that it contributes to the personal and professional development of the candidate teacher in different dimensions. Some of examples from mentors about effectiveness of the program: 
(T.1) "An effective process was experienced. The candidate teacher saw our experiences, knowledge and skills." (T.4) "It was absolutely influential as the candidate did not know what to do when he was nominated. He watched us and saw what he had to do. He gained a perspective about the job. He showed a lot of progress in the process."

(T.32) "My candidate teacher was a teacher who was waiting for being nominated for years and was finally started teaching. Actually, he seemed to have lost a little in his thrill. But in the process, he got excited again. Perhaps watching us, he saw what he had to do. After all, he liked the students and he did his best for them. I think that it is a positive process because he gave lecture by coming to the school willingly."

By using these expressions, the mentor teachers stated that this program is effective in changing the candidate teacher's perception about teaching in a positive way. With this positive perception, another aspect emerging from the effectiveness of the program was the recognition of the functioning of the school and the system. Thus it enabled professional development. In this respect, "It was an effective program. At least he had information about how the school worked." T.17 said. (T.20) stated, "I think this process is influenced by the candidate teacher's positive perception of the profession. I think it was an effective process because he was in the school environment and he felt the beauty of being able to convey something to the students, and this made him even closer to his profession." Another mentor (T.35) said, "It was an effective program. Our teacher had the opportunity to get to know the profession more closely and he had a positive opinion about the teaching profession." In addition, (T.19) said, "I think the process was effective; because he had an idea about what he should do in order to improve himself by standing among the teachers." Besides the personal development of the candidate, the suggestion that it contributed to the candidate in great sense also proved that the candidate teacher acquired the characteristics of trust, excitement, and willingness. In this regard some of examples from mentors:

(T.22) "The process was effective in favor of the candidate's perception in the positive direction. At any rate, the confidence of the candidate teacher at the end of the program has increased. It is possible to see this from his behavior."

(T.30) "The candidate teacher came to us with enthusiasm. As we entered, the classes together and he became familiar with the students. I think he is more willing to fulfill his job."

(T.34) "As time passed in school, I think that his sense of initial intimacy decreased. He overcame his excitement in a sense."

It has been one of the opinions stated that the Candidate Teacher Training Program is an effective training process for the mentor teachers themselves through the exchange of information and experience. The opinions expressed by the mentor teachers on the ineffectiveness of the process are shown in the following table:

Table 3. Participant Opinions regarding non-effectiveness of process

\begin{tabular}{lccc}
\hline Opinions & Category & f & Total \\
\hline $\begin{array}{l}\text { Candidate teacher has previous } \\
\text { teaching experience }\end{array}$ & Originating from the candidate teacher & 2 & \\
$\begin{array}{l}\text { Careless behavior of the candidate } \\
\text { teacher }\end{array}$ & & 3 \\
\hline Lack of motivation & & & \\
\hline
\end{tabular}

As stated in the table 3, the reasons resulting from the candidate and the mentor teachers for not being effective of the process were expressed. In this issue (T.6) said, "My candidate teacher was already working as a teacher but not being nominated. Moreover, he was accustomed to this atmosphere. Therefore, I can't say that the program is effective for him." (T.14) stated, "I do not think that this program has any effect on the perception of the candidate teacher about the teaching profession since the candidate teacher is not very regular. I do not mean it to be influential in this respect." Another notion, which has been expressed in the direction that the mentor teacher can't adopt the process is that education is not effective. In this issue (T.2) expressed, "I was very enthusiastic at the beginning. I did not have the contribution as I wanted. After a while, things became commonplace. I expected an extra wage. As there was no, I lost my enthusiasm."

3.2 Opinions of Mentor Teachers' on the Contributions of the Candidate Teacher Training Program to the Candidate Teachers

In addition to the efficacy of the program, it is also a sub-problem of this research whether the training period of the mentor teachers, which is a part of the process, contributes to the candidate teachers. To determine this, mentor teachers were asked, "What are your views on whether the Candidate Teacher Training Program contributes to candidate teachers?" Except for one mentor, all expressed that this program contributes to the candidate teachers. The following 
is a table of contents analysis based on the opinions of mentor teachers regarding the contribution of candidate teachers in terms of the subject:

Table 4. Opinions about the contribution of the program to the candidate teachers

\begin{tabular}{|c|c|c|c|}
\hline Expressions & $\mathbf{f}$ & Category & f \\
\hline Student guidance & 1 & \multirow{3}{*}{ Recognizing the student } & \multirow{3}{*}{5} \\
\hline Communication with students & 3 & & \\
\hline Evaluation of student behavior & 1 & & \\
\hline Seeing own shortcomings & 1 & \multirow{14}{*}{$\begin{array}{l}\text { Acquiring educational-instructional } \\
\text { competence }\end{array}$} & \multirow{14}{*}{26} \\
\hline Throwing excitement & 1 & & \\
\hline $\begin{array}{l}\text { Gaining experience with the problems possible to } \\
\text { encounter }\end{array}$ & 6 & & \\
\hline Professional experience & 2 & & \\
\hline Seeing the finesse of the profession closely & 1 & & \\
\hline Lecture skills & 2 & & \\
\hline Course preparation skills & 1 & & \\
\hline Classroom management skills & 4 & & \\
\hline Class discipline & 1 & & \\
\hline Practicing learning skill & 1 & & \\
\hline Increasing in knowledge level & 1 & & \\
\hline Increasing in culture level & 2 & & \\
\hline Experiencing the teaching & 2 & & \\
\hline Increasing pedagogical knowledge & 1 & & \\
\hline Recognition of management & 2 & \multirow{4}{*}{ Obtaining managerial information } & \\
\hline Recognition of revolving funds & 1 & & \\
\hline Learning the legislation & 2 & & \\
\hline Recognition of education system & 3 & & 8 \\
\hline Getting to know the colleagues & 2 & \multirow{7}{*}{ Recognition of school and social environment } & \multirow{7}{*}{13} \\
\hline Individual relations & 1 & & \\
\hline Recognition of school function & 4 & & \\
\hline Review of regulations & 1 & & \\
\hline Experiencing various applications within the school & 2 & & \\
\hline Recognizing the environment & 2 & & \\
\hline Getting to know institutions & 1 & & \\
\hline
\end{tabular}

As can be seen in the table 4, the opinions of the mentor teachers' contribution to the Candidate Teacher Training Program are grouped under the categories of "recognizing students, acquiring educational instructional competence, obtaining managerial information, recognition of school and social environment". According to the mentor teachers, the most contributing factor of the program to the candidate teachers was the category of "acquiring educational-instructional competence". Mentor views in this category, the program provided the candidate with teaching experience and classroom management have become more often voiced. For example: (T.5) said, "Candidate teacher has gained experience. They got the chance to observe by entering a class at the guidance teacher's meeting. In this way they observe our truths and faults as mentor teachers. They went to their own school as an experienced teacher but not as an inexperienced one." With these expressions, he said that during the program they had the opportunity to see the right and wrong of the mentor teacher. "The process of preparing the course seemed to be a detail at the beginning, but it was soon understood by the candidate teacher how important this process was for the profession. The process of experience gained in subjects such as classroom management and individual relations was a positive aspect of the program. For instance, besides many examples that can be given, our candidates said that he did not learn at university during the four years as much as he learnt for the four weeks here and this was the most concrete example of the contribution of the program to the candidates." (T.31) said. By this way, the mentor stated that the candidate teacher gained the experience, which he couldn't get at university education process, and stressed the experiences gained about the preparation for classroom management and interpersonal relations. (T.32) said, "This is the excitement of the first year, a little bit of being 
inexperienced. He has gained experience in teaching classroom discipline, giving lesson to the students and filling the class book." (T.33) said, "The most important opportunity this process gives to the candidate is the experience of the profession. A new graduate teacher has gained vocational experience through this practice. He will surely do better at his job." (T.35) said about the contribution of the program, "He established a link between experience and trust and found the opportunity to see closely the subtleties of the teaching profession besides an experienced teacher. His self-confidence increased and he survived his first nuisances." (T.28) in connection with the lack of experience in the first years of his teaching said, "I was nominated to the school of in a village and suffered very much. In fact thanks to this practice they have experience, I think it is very valuable for them to experience some things in the presence of a guide teacher instead of going directly to the school." Regarding the experience gained in classroom management by means of this program (T.12) stated, "The candidate developed himself in terms of class management before he started his own school as a teacher which is an experience to be gained by practicing." (T.17) expressed that the candidate was able to foresee situations, which would be encountered in classroom management. "The candidate teacher benefited from seeing how the students were managed in the classroom and from having experience in managing it in our own accord." T.17 said.

In addition to classroom management, mentor teachers have also voiced the ability to teach lectures. For example (T.10), "I think that the greatest contribution was the experience before the beginning of his own school. The absence of any teaching experience at the time of entering the course for the first time in his or her school can sometimes have a negative effect on the teacher. As a teacher, he experienced the introduction and the presentation of the lesson." By saying so, the mentor teacher handled the classroom instructional dimension in the context of the course execution.

As a second contribution to the candidates, mentor teachers have stated that the program contributes to the identification of the school and the social environment. The views expressed in this regard suggest that candidate teachers are able to identify both the educational system and the school system in different dimensions. For example (T.7) expressed, "Contribution was so great. It contributed to see how the teachers should behave in the school, also to see how the system and its functioning was. He reviewed the regulations. He had the opportunity to get to know the school and its surroundings." By this way, the mentor teacher stressed getting to know the behavior and the process at school. (T.29) stated, "It also contributed to the recognition of the process in the school's work. The experience of the teaching profession and being at school increased. He saw the work and the practices, and he had experience with how it worked." In terms of school recognition as a whole, (T.15) stated, "I think that in general he saw the functioning of the school in different dimensions. He experienced many things for the first time. He became more ready than the teacher who was nominated in the previous system and entered the course on the same day." Interaction with the colleagues was also mentioned as another contribution. For example in this issue (T.11) said, "I think they have had a high contribution period. At least the experience and the identification of different colleagues broadened his educational environment."

Another type of contribution that emerges in the opinions of the mentor teachers is that the candidate teachers have knowledge at the administrative level. For example, in this issue (T.1) said, "Candidate teacher gained experience. He saw the school work. He saw the school's administration. He saw what the managers did." (T.6) said, "Absolutely it contributed. He saw in every respect the functioning of school and the school. He recognized the revolving fund operation there." (T.9) stated, "It had a positive contribution in the full sense. The candidate comprehends the working system more quickly both in terms of formal studies and educational dimension."

Another aspect of the Candidate Teacher Training Program that the mentor teachers express about the contribution to the candidate teachers is the "recognizing the student" category. The opinions expressed in this regard are stated as having information about student guidance, having experience in communicating with the student and evaluating student behaviors. Teachers, who have guidance duties so that students can live their lives in accordance with their abilities (Pektaş \& Kamer, 2011), have gained experience in recognizing and guiding students during their first years of profession.

\subsection{Thoughts on the Challenges Faced by Mentor Teachers in the Candidate Teacher Training Program}

In the scope of the Candidate Teacher Training Program, there are in-service training activities including in-class and in-school monitoring activities, teaching practices, out-of-school activities, and exam topics included in the 20th and 21st articles of the Ministry of Education Teacher Appointment and Relocation Regulation (MONE, 2016). Mentor teachers directly participated in these activities with the candidate teachers. Apart from this, the books that the candidate should read and the films the candidate should watch are also in the process. In this context, the mentor teachers have been given the task of educating candidate teachers as a model through their transfer of experience as well as their professional knowledge, skills, attitudes and behaviors. Therefore, in this training process, mentor teachers have more interaction with the candidate teachers than the other shareholders do. The question "Are there any difficulties you have encountered during the Candidate Teacher Training Program? If so, what are these difficulties?" were asked to determine the challenges faced by mentor teachers during the process. While 3 of the mentors stated that they did not 
encounter any problems, the other participants expressed one or more problem areas. Accordingly, the content analysis table based on the opinions of the mentors about the difficulties during the program is shown below:

Table 5. Opinions regarding challenges encountered during the program

\begin{tabular}{|c|c|c|c|}
\hline Expressions & $\mathbf{f}$ & Category & $\mathbf{f}$ \\
\hline Excess of documents and reports & 22 & \multirow{7}{*}{ Waste of stationery } & \\
\hline Fatigue of paperwork & 1 & & \\
\hline Taking the time of paperwork & 3 & & \\
\hline Filling official documents & 2 & & \multirow{4}{*}{31} \\
\hline A waste of paperwork & 1 & & \\
\hline Unnecessary and wasteful for the candidate teacher & 1 & & \\
\hline Procedure to the candidate teacher & 1 & & \\
\hline Candidate's coming from different cities & 2 & \multirow{7}{*}{$\begin{array}{l}\text { Problems due to the } \\
\text { candidate }\end{array}$} & \multirow{7}{*}{9} \\
\hline The weakness of the candidate's disciplinary mastery & 2 & & \\
\hline Indifference of candidate & 1 & & \\
\hline Candidate teacher's not adapting the school & 1 & & \\
\hline Failure of the candidate to follow the technology & 1 & & \\
\hline Motivation problem with students & 1 & & \\
\hline Compensation lessons made with the candidate teacher & 1 & & \\
\hline Time inadequacy & 2 & \multirow{6}{*}{ Application process } & \multirow{6}{*}{8} \\
\hline The lack of time for the candidate activities & 1 & & \\
\hline Time-consuming applications & 1 & & \\
\hline Diversity / type of application in the process & 1 & & \\
\hline $\begin{array}{l}\text { The tiredness because of the official document (Weekly } \\
\text { Plan) }\end{array}$ & 1 & & \\
\hline No additional tuition fees & 2 & & \\
\hline Computer need & 2 & \multirow{3}{*}{ Need for tools } & \multirow[b]{3}{*}{5} \\
\hline Printer need & 1 & & \\
\hline Book and movie need & 2 & & \\
\hline
\end{tabular}

As seen in the table 5, the difficulties encountered during the Candidate Teacher Training Program can be grouped into four categories as "waste of stationery, problems due to the candidate, application process and need for tools".

Among these categories, the category in which the most opinions are gathered are "waste of stationery" category. Mentor teachers who categorized their views in the category of "waste of stationery" have put forward more opinions on the excess of documents and reports. Some of examples from mentors:

(T.3) "We filled up the daily, hourly documents in the process. This may be simpler. We could not do the job because of filling out the paperwork. It took a lot of time. Document work can be reduced ..."

(T.8) "For us, the official dimension of this work was to fill in forms and papers. It took time."

(T.26) "There were lots of documents we had to fill."

It is another voiced opinion that the forms, which the mentors have to fill in, are an obstacle in terms of taking time and using the time efficiently. In this issue (T.16) said, "The only problem is the exaggeration of the paperwork. It made us use the time not effectively." Similarly, (T.15) expressed, "The basic problem was that there were too many paperwork burdens. Sometimes we cannot even focus on what we really need to do. Fill this, fill that. This paper work must be strictly reviewed so that the time is better used." Some mentors have expressed this problem in terms of candidate teachers. For example, (T.29) said, "There are too many procedures on the candidate teacher. It may be difficult to allocate the necessary time as a timetable." and he expressed that because of too many paper works they couldn't use the time effectively. (T.4) said, "It is waste of the excess of documents. There were very detailed documents. I see this unnecessary for the candidate. I think this is a waste." By saying so, he stressed the waste of paper work. (T.12) stated, "The desired paperwork for the candidate teacher should be less for efficient use of the time."

There is another opinion emerging in this category that the filled-in forms influence the motivation of the mentors. For example, (T.28) said, "There was official paperwork. We have not encountered any difficulties other than those documents. If these documents are reduced, we would like to do our work and our duty willingly." (T.30) stated, "The only difficulty for me was that the paperwork took a lot of time from time to time. If the work of paperwork is reduced a little, I think that the mentor teacher will do more with his work." They stated that it would be more effective to reduce the 
number of the forms in order to make the teachers more engaged in this process. Referring to the fact that the process is likewise passable, (T.21) said, "We had to postpone our other works because of the documents we had to fill up from time to time. It was very enjoyable except for the density of the paperwork." To reduce the amount of filling the form as a factor that enhances the willingness of the mentors to participate in the process, (T. 32) said, "I do not have a problem, but I think that the documents required to be filled in each sheet are redundancy and burden. The mentor teacher will be more willing to reduce the work of paperwork."

The second frequently mentioned issue regarding the difficulties during the program was the category of problems due to the candidate. The problems seen in this issue are the lack of motivation of the students in the lectures, the candidate teacher's residence in a different place, the weakness of the candidate's disciplinary mastery, the indifference in the process and the school ownership. To illustrate, (T.13) stated, "The candidate teacher, whom I consulted, went to his home city every week because he stayed in a different country. On some days, he asked me if he could leave early on that day. It is more logical that this process takes place on his own school's district." According to the mentor, the candidate did not feel that he belonged here so much as he would leave here after four months. (T.5) said about the inexperience of the candidate "Since the candidate teacher is inexperienced in his branch, we have had problems with the branch. The weakness of the candidate's disciplinary mastery is the main reason for this problem." (T.7) said similarly, "The candidate teacher was not particularly well equipped for vocational courses. In many lessons, he would have seemed to be in trouble if I had told him to put up with the lesson. The candidate has poor knowledge of the branch. He could not follow the technology in general."

Problems arising from the implementation process of the program are frequently mentioned in the third place regarding the difficulties during the program. Problems that are grouped in this category are the inadequate time for applications and for the candidate to practice teaching, the loss of time for some of the applications, the diversity of applications in the process, the necessity of making Weekly Plans instead of Monthly Plans, and not having extra wages.

Another problem area that emerged in the opinion of the mentors regarding the Candidate Teacher Training Program was the need for a tool in the process. In order to fill out the forms, a computer and a printer are required to type and print these forms. There have been problems about the films and books which they must watch and read. They have difficulties in finding of these films and books in order to be able to watch and read.

\subsection{Opinions of Mentor Teachers about Planning a Candidate Teacher Training Program More Effectively}

As the candidate teacher is one of the most active members of the training program of the mentor teachers who have the duty to train their colleagues with experience and knowledge in the Candidate Teacher Training Program, the question was asked to the mentor teachers "How can you plan the Candidate Teacher Training Program more effectively?" The content analysis table based on the opinions of the mentors is shown below: 
Table 6. Opinions regarding more effective planning of the program

\begin{tabular}{|c|c|c|c|}
\hline Expressions & $\mathbf{f}$ & Category & $\mathbf{f}$ \\
\hline It is applied in the first semester, but not in the second one. & 1 & \multirow{6}{*}{$\begin{array}{l}\text { Opinions about the } \\
\text { duration of education }\end{array}$} & \multirow{6}{*}{9} \\
\hline It is applied in both semesters, but not only one. & 2 & & \\
\hline The process is extended and the candidate gains more experience & 1 & & \\
\hline The process is extended and the candidate has more time in school & 3 & & \\
\hline Program can be abbreviated. & 1 & & \\
\hline Being applied during the seminar period & 1 & & \\
\hline $\begin{array}{l}\text { The activities that make the candidate teacher more active can be } \\
\text { applied. }\end{array}$ & 2 & \multirow{8}{*}{$\begin{array}{l}\text { Opinions about the } \\
\text { candidate's education }\end{array}$} & \multirow{8}{*}{21} \\
\hline Candidate teacher should teach more & 2 & & \\
\hline Candidate teacher can spend more time at school & 1 & & \\
\hline Candidate teacher should be able to see different schools & 3 & & \\
\hline Making the program where the candidate teacher is assigned & 7 & & \\
\hline Candidate teacher should be trained at the same school type & 2 & & \\
\hline $\begin{array}{l}\text { Candidate teacher should be given the consultant teacher with the same } \\
\text { branch }\end{array}$ & 2 & & \\
\hline Candidate teacher should be able to follow lessons from different teachers & 2 & & \\
\hline Priority should be given to the practice rather than paperwork & 2 & \multirow{3}{*}{$\begin{array}{l}\text { Opinions regarding } \\
\text { official documents }\end{array}$} & \multirow[b]{3}{*}{14} \\
\hline School plans should be put in place instead of procedure & 2 & & \\
\hline Documents work should be reduced & 12 & & \\
\hline Mentor teacher should have more flexibility & 1 & \multirow{4}{*}{$\begin{array}{l}\text { Opinions regarding } \\
\text { mentor teachers }\end{array}$} & \multirow{4}{*}{10} \\
\hline Supervisor teaching fee should be given to the mentors & 2 & & \\
\hline Counselor should be provided incentives such as award & 3 & & \\
\hline Mentor teacher training seminars are effective & 4 & & \\
\hline The process is well designed. The current application is sufficient & 3 & \multirow{2}{*}{$\begin{array}{l}\text { Opinions regarding the } \\
\text { sufficiency of the } \\
\text { current situation }\end{array}$} & \\
\hline The program does not show any problems. It is well-planned & 1 & & 4 \\
\hline $\begin{array}{l}\text { No such training is necessary. We need to pay serious attention to teaching } \\
\text { practices in college }\end{array}$ & 1 & \multirow{2}{*}{$\begin{array}{l}\text { Opinions regarding the } \\
\text { necessity of the } \\
\text { program }\end{array}$} & \multirow[b]{2}{*}{2} \\
\hline No need for program. Procedure has already be loaded. & & & \\
\hline
\end{tabular}

As can be seen from the table 6, the opinions of the mentor teachers regarding the more effective planning of the Candidate Teacher Training Program have appeared in the categories of "ideas about the duration of training, candidate education, official documents, mentor teachers, the adequacy of the program in current form and the necessity of the program". Among these categories, the most reported opinions were "opinions about the candidate's education". Among the opinions in this category, the most frequently stated opinion was that "The program is to be done by the candidate teachers in the city where they have been nominated." For example, in this issue (T.4) said, "I think that the candidate teacher is to take this education process in the school he is nominated to. The consulting process should be conducted at that school. Either a teacher or a teacher from another school should advise him / her about the process. So, he wouldn't have difficulty in getting used to the school again." Mentor described this as a getting used to process. In evaluating the process of taking the candidacy training at school, (T.5) said, "It is more useful to have this process on the candidate's nominated place and it may make more sense to take this training in his own school. Since the candidate teacher was from here, his house was here, and his eyes kept the watch, he was in a hurry to leave the school. He could have spent more time at his school where he was nominated." (T.17) said, "When this training is planned, it must be done in such a way that the candidate teacher takes this training at the nominated place. If this training is aimed at harmonizing the candidate, he will have to adapt to it again upon going from here to the east. Because of this, in his own city the candidate would get to know both the surrounding and the school more effectively." It is said that the candidate teacher is required to have this training in his / her nominated place in terms of easier adaptation to the region where the candidate teacher is nominated.

Apart from these views, in this category it is stated that the candidate teacher should be more active for more effective planning of the program. More time should be spent in the school and in classroom lectures. For example (T.3) stated that "The candidate teacher should be given more active duty. He sat down and watched us for six weeks. Then he lectured for an hour. He should tell more lessons and enter lessons." One of the things that was reported in this category was that the candidate teacher should also see different schools. For example, in this issue (T.24) stated, "The candidate should take 
this education not at one school but at different schools before starting the profession. Thus, students should see the lessons of their colleagues in other schools and gain experience." By saying so, he suggested that the candidate should follow his colleague in more than one school in order to gain experience. Other participants whose opinions are assessed in this category suggest that the candidate teacher should be educated in the same school type and the same branch mentor teachers should be appointed to them.

In the opinion of mentor teachers regarding the more effective planning of the Candidate Teacher Training Program, the second category is the "official documents" category, which is highly viewed. In the implementation of the Candidate Teacher Training Program, some forms were used by the General Directorate of Teacher Training and Development, and were adapted by their teachers and mentors according to their class, school and environment conditions (MONE, 2016). Reducing these forms used in the training process was considered important by the participants in planning the process more effectively. For example, in this issue (T.20) said, "The process should be purified from filling the documents as much as possible. The number of paperwork must be reduced. The overall evaluation should be made in a way that can be written. Otherwise, the procedure does not go beyond that." He stated that the forms which he called "document filling" would be seen as a procedure and a surplus of processing work. Similarly, (T.33) said, "Instead of doing everything or taking every step according to the regulations on paper, the teacher should be provided with freedom and have a chance to take his own responsibility. At the end of the process, I think that a general paper can be filled for each activity type." The surplus of filling forms is also expressed by referring to have more time in the classroom instead of filling out the form. In this issue (T.26) stated, "The work of paperwork should be reduced and the candidate teacher should go in and out of the class more than dealing with paper too much. The main function should be gaining experience in the course of business." Similarly (T.30) said that "I think it would be more beneficial for the candidate teacher to enter the class rather than to deal with the official documents too much. Normally, the teacher does not have much work with official paperwork. In this process, I think the longer the candidate teacher lives the lesson experience, the more useful it will be."

Another category emerging from content analysis based on the opinions of the mentor teachers is the opinions about the mentor teacher. Within these views, it has been revealed that more flexibility should be provided to the mentor teachers, additional tuition fees should be paid to the mentor teachers involved in the training process, various awards or incentives should be provided, and seminars in which the mentor teacher trainings are held should be carried out more effectively. Regarding the mentor teacher trainings (T.27) said, "The mentor teacher seminars were inadequate in my opinion. The duration should be kept longer and more practical examples should be shown. Planning can be done according to them." In this way, mentor emphasized the duration of training and sample diversity. (T.31) said, "When the seminar we attended is taken into consideration, it can be stated at the end of it that the process is insufficient. This issue can be planned again."

In the more effective planning of the Candidate Teacher Training Program, there have been opinions expressed by participants. In these views, regarding the inadequacy of the time, (T.15) said, "The candidate teacher came at the beginning of the second semester and went at the end of the semester. This period can be longer. The candidate teacher will gain more experience if he / she completes an academic year in this way." Similarly, (T.21) about the inadequacy of the time said, "The candidate teacher stayed for four months with us. I think that this program can be spread over an academic year so that the candidate teacher can spend more time with the mentor and experience the process. In addition to insufficiency, it should be done at the beginning of the semester." (T.31) said, "I think that this process will be more useful if it is done in the first period. The candidate can also see the works to be done before the beginning of the school year. " One participant noted that the program could be shortened as it is sufficient, and that the program was sufficient, and a participant said that the program can be done during the seminar period.

In addition to these views, two participants stated that there was no need for such an educational program, while four participants expressed that the current operation was adequate and that the planning was appropriate and that no adjustment was necessary. It was emphasized in two participants' views that serious attention to teaching practices in universities would remove the need for the program and that the continuing procedural burden would make the program unfeasible.

\section{Discussion and Conclusion}

The findings of this study can be evaluated in terms of the effectiveness of the program, the contributions of the program to candidate teachers, the difficulties in the program and more effective planning of the program.

According to the findings of this study, 26 of the mentors evaluated the Candidate Teacher Training Program applied for the training of candidate teachers as an effective training process. Participants noted that the Candidate Teacher Training Program was effective in contributing to the personal and professional development of the candidate teacher in different dimensions. Similarly, the study conducted by Şayir and Yardibi (2017) noted that despite the shortcomings the program, the program had great contribution to professional development of the candidate teachers. According to another finding 
of effectiveness of the program, the program is an effective training process contributing to the mentor teachers through the exchange of both knowledge and experience. However, 5 of the mentors who participated in this research stated that the program was not effective, and for 5 mentors it was partially effective. In this case, the process of the program was generally found effective by the mentors. Similarly, in a study conducted by Dursun, Bulut and Yenen (2016), mentor teachers stated that they found the education process as an important and positive application in general.

According to the findings of this study in terms of contributions to candidate teachers, except for one mentor, all the mentors think that this program contributes to the candidate teachers. The contribution of the program to the candidate teachers was revealed in the categories of "recognition of the student, acquisition of educational-instructional competence, acquisition of managerial knowledge, recognition of school and social environment".

According to the findings obtained about the difficulties encountered during the Candidate Teacher Training Program, the mentor teachers stated that they had difficulty in four categories as "waste of stationery, problems arising from candidate, application process and tools and equipment". This difficulty has been a problem expressed both in terms of both mentor teachers and in terms of candidate teachers. The excess of documents and reports are often expressed in these views expressed in the category of waste of stationery. It has been stated that the excess of documents and reports is also an obstacle to efficient use of time and is a motivation-reducing factor. The surplus of paperwork also became an important problem area expressed by the mentor teachers (Topsakal \& Duysak, 2017; Apaydın, Çelik Şahin \& Karasu, 2017; Şayir \& Yardibi, 2017). In our research, some mentors stated that the application of filling in forms should be continued even if it should be reduced. Similarly, Pala (2017) also concluded in his survey that the number of the mentor teachers has to be reduced and the filling of the form has to be continued.

Another finding of the research is that the opinions of the mentor teachers regarding the more effective planning of the Candidate Teacher Training Program concentrated on the candidate's education style, official documents, mentor teacher and the duration of the training. In the opinion of mentor teachers, the idea of "making the program in the city where the candidate teacher is nominated" has been the subject of more frequent mention about the candidate's training. The idea that the candidate teacher should have this training program in the city or school where he is nominated was seen important in terms of both effective intervention and easier integration with the city. Apart from this, for the candidate teacher to become more active, to spend more time at school and in class were considered necessary by the participants in the effective planning of the process. A conclusion about the more effective planning of the program is that more than half of the mentor teachers stated that the forms filled in the process are regarded as procedures and therefore both the type and the number of the forms should be reduced. Some participants stated that it is more important to give the candidate the teaching lesson experience instead of filling out the form.

Another finding of the research is to give more flexibility to the mentor teachers, payment of additional tuition fees to the mentor teachers involved in the training process, provision of various awards or incentives, and more effective implementation of the seminars where the mentor teacher trainings are given. In another research, it has become a topic the mentor teachers have expressed about the program that it should be more productive (Toprakçı \& Ölmez Ceylan, 2017). In addition to this, a more effective planning of the Candidate Teacher Training Program is more voiced than the views on the adequacy and redundancy of the program. In this context, the progress should be in two terms and the candidate should gain more experience from the beginning of the first term. In the research conducted by Toprakçı \& Ölmez Ceylan (2017), the mentor teachers stated that the candidate period should be started at the beginning of the academic year and should be continued for one year.

As a result, it is necessary to overcome the difficulties expressed by the mentor teachers who are at the center of the practice so that the Candidate Teacher Training Program can be implemented more effectively and productively. It should be tried to develop the program by taking the views of all participants involved in the process of the Candidate Teacher Training Program in the first months of the teaching career. In this research, according to the mentor teachers' opinions about the place to give the training to the candidate teachers, it can be made possible to make the candidacy training in the place where they are nominated so that the adaptation to the schools can be achieved faster. The mentor can be arranged in such a way as not to increase the stationary load of the teachers and to be made through computer systems. Regarding the training of the mentor teachers, it is possible to take into consideration the volunteerism in the selection of the mentor teachers and the preference of the teachers who have professional excitement in this work. In addition, it may be advisable to give an additional tuition fee per week in order to ensure that the mentor teachers are motivated. 


\section{References}

Akar, H. (2016). Durum çalışması [Case Study]. In A. Şaban \& A. Ersoy (Eds.), Qualitative research patterns in education (pp. 111-149). Ankara: An1.

Akyüz, Y. (2012). Effects of teachers in social change in Turkey (1839-1950). Ankara: Pegem Akademi.

Ambrosetti, A., \& Dekkers, J. (2010). The interconnectedness of the roles of mentors and mentees in pre-service teacher education mentoring relationships. Australian Journal of Teacher Education, 35(6). https://doi.org/10.14221/ajte.2010v35n6.3

Apaydın, G., Çelik, Ş. A., \& Karasu, N. (2016). Examination of advisor, candidate teacher and manager opinions related to the mentor system in the process of candidate teacher training, Paper presented at the Proceedings of the 2nd International Academic Research Congress. Retrieved from https://2017.inescongress.com/docs/abstract-book.pdf

Başar, M., \& Doğan, Z. G. (2015). Social, cultural and vocational problems that the novice teachers face. Route Educational and Social Science, 2(4), 375-398. https://doi.org/10.17121/ressjournal.430

Boreen, J., Johnson, M. K., Niday, D., \& Potts, J. (2009). Mentoring beginning teachers: Guiding, reflecting, coaching (2nd ed.). Portland, ME: Stenhouse.

Celkan, H. (2014). Education and society. In M. Ç. Özdemir (Ed.), Sociology of education (pp. 39-66). Ankara: Pegem Akademi.

COHE (The Council of Higher Education). (2006). An explanation about new programs to be implemented in education faculties.

Retrieved

from http://www.yok.gov.tr/documents/10279/49665/aciklama_programlar/aa7bd091-9328-4df7-aafa-2b99edb6872f

Creswell, J. W. (2007). Qualitative inquiry \& research design choosing among five approaches (2nd ed.). Thousand Oaks, CA: Sage.

Duman, T. (2014). Practices and developments in teacher training. In C. Özdemir (Ed.), An introduction to educational science (pp. 331-351). Ankara: Pegem Akademi.

Dursun, F., Bulut, A., \& Yenen, E. T. (2016). Candidate and counselor teachers' views towards candidate teacher training process, Paper presented at the Proceedings of the 1st International Symposium on Social Sciences. Retrieved from https://asoscongress.com/2016/ozet_kitap_final.pdf

Ekiz, D. (2009). Scientific research methods (2nd ed.). Ankara: Anı.

Genç, S. Z. (2005). Problems encountered with elementary teacher training. Journal of Kazım Karabekir Education Faculty, 11, 86-99.

Gordon, S. P., \& Maxey, S. (2000). How to help beginner teachers succeed (2nd ed.). Alexandria, VA: Association for Supervision and Curriculum Development.

Klieger, A., \& Oster-Levinz, A. (2015). The influence of teacher education on mentor teachers' role perception in professional development schools, Journal of Education for Teaching, 41(2), 115-127. https://doi.org/10.1080/02607476.2015.1010873

Kwan, T., \& Lopez-Real, F. (2005). Mentors' perceptions of their roles in mentoring student teachers. Asia-Pacific Journal of Teacher Education, 33(3), 275-287. https://doi.org/10.1080/13598660500286267

Miles, M. B., \& Huberman, A. M. (1994). An expanded sourcebook qualitative data analysis. (2nd ed.). Thousand Oaks California: Sage Pablications.

MONE (Ministry of National Education). (2016). Directive on the candidate teacher training process, Millî Ĕgitim Bakanlığı Tebliğler Dergisi [MONE Journal of Tebliğler], 79 (2702).

Odell, S. J., \& Ferraro, D. P. (1992) Collaborative teacher induction. In G. P. DeBolt (Ed.), Teacher induction and mentoring: School-based collaborative programs. Albany, NY: State University of New York Press.

Pala, A. (2017). The teacher mentoring process applied to teacher canditates appointed to primary and secondary schools. (Unpublished Master’s Thesis). Gaziantep University, Institute of Educational Sciences, Gaziantep.

Pektaş, M., \& Kamer, S. T. (2011). The attitudes of science teacher trainees for teaching profession, The Journal of Turkish Educational Sciences, 9(4), 829-850.

Resmi Gazete [Official Gazette] (2015). Ministry of National Education, teacher appointment and relocation regulation. Date: 17.04. 2015, Issue: 29329, Retrieved from http://www.resmigazete.gov.tr/eskiler/2015/04/20150417-4.htm 
Şayir, G., \& Yardibi, N. (2017). Opinions of consultant teachers on evaluating the candidate teacher training process. Cappadocia Journal of History and Social Sciences, 8, 140-150. https://doi.org/10.18299/cahij.112

Smith, A. A. (2007). Mentoring for experienced school principals: Professional learning in a safe place, Mentoring \& Tutoring, 15(3), 277-291. https://doi.org/10.1080/13611260701202032

Tavşancıl, E., \& Aslan, E. (2001). Content analysis and case studies, İstanbul: Epsilon.

TDK (2017). The great Turkish dictionary. Retrieved from
http://www.tdk.gov.tr/index.php?option=com_bts\&arama=kelime\&guid=TDK.GTS.5a05e553273052.58459202

Toker, G. A. (2013). Classroom teachers' professional problems in their induction period. Dicle University Journal of Ziya Gökalp Faculty of Education, 21, 137-156.

Toprakçı, E., \& Ölmez, C. Ö. (2017). Process of transition to primary teachers' views according to the views of candidate and mentor teachers and school principals. Paper presented at the 12th International Education Management Congress. Retrieved from http://eyk12.eyedder.org.tr/wp-content/uploads/2017/05/12UEYK-Bildiri-Özetleri-Kitabı-1.pdf

Topsakal, C., \& Duysak, A. (2017). Opinions of candidate teachers and other stakeholders related to the candidate teacher training process. Sakarya University Journal of Education, 7(3), 625-638. https://doi.org/10.19126/suje.368228

Tünay, T. (2017). Percieve of relevant parties to candidate teacher training process of Ministry of National Education. (Unpublished Master's Thesis). Karabük University, Institute of Social Sciences, Karabük.

Tunçbilek, M. M., \& Tünay, T. (2017). Percieve of relevant parties to canditate teacher training process of Ministry of National Education in Turkey. Electronic Journal of Social Sciences, 16(61), 412-427.

Ulubey, Ö. (2018). Evaluation of novice teacher training program. Hacettepe University Journal of Education, 33(2), 480-502. https://doi.org/10.16986/HUJE.2017031014

Veenman, S. (1984). Perceived problems of beginning teachers. Review of Educational Research, 54(2), 143-178. https://doi.org/10.3102/00346543054002143

Yıldırım, A., \& Şimşek, H. (2013). Quantitative research methods in social sciences. Ankara: Seçkin Publishing.

Y1lmaz, K., \& Kab, İ. (2013). Social studies teacher candidates' thoughts about and evaluations of 'school experience' and 'teaching practicum' courses. Humanitas, 1(1), 197-215.

Y1lmaz, M. (2017). Problems encountered during candidate teacher training and suggested solutions. Education and Society in the 21st Century, 6(16), 135-155.

\section{Notes}

Note 1. Earlier drafts of this paper were presented at the International Education Management Forum, Ankara, Turkey, October 2017.

\section{Copyrights}

Copyright for this article is retained by the author(s), with first publication rights granted to the journal.

This is an open-access article distributed under the terms and conditions of the Creative Commons Attribution license which permits unrestricted use, distribution, and reproduction in any medium, provided the original work is properly cited. 